\title{
Leucocyte function in children with kwashiorkor
}

\author{
E. U. ROSEN, J. GEEFHUYSEN, R. ANDERSON, M. JOFFE, and A. R. RABSON \\ From the Department of Paediatrics, Baragwanath Hospital and the University of the Witwatersrand; \\ and Department of Microbiology, School of Pathology, University of the Witwatersrand and The South \\ African Institute for Medical Research
}

\begin{abstract}
Rosen, E. U., Geefhuysen, J., Anderson, R., Joffe, M., and Rabson, A. R. (1975). Archives of Disease in Childhood, 50,220. Leucocyte function in children with kwashiorkor. A study of leucocyte response to infection, polymorphonuclear leucocyte chemotaxis and bactericidal activity, and nitroblue tetrazolium (NBT) reduction in children with kwashiorkor was undertaken and compared with a control group. The results show that total leucocyte counts were depressed in children with kwashiorkor, and lymphopenia was not infrequent. NBT reduction was normal. Abnormal polymorphonuclear leucocyte chemotaxis and bactericidal activity, though frequently found in children with kwashiorkor, was shown to be dependent on infection and not on protein depletion per se. Therefore, apart from some impairment of leucocyte mobilization in the presence of infection, the quality of polymorphonuclear function, as determined by the above techniques, appears to be normal in kwashiorkor.
\end{abstract}

The association of infection with malnutrition has long been appreciated (Scrimshaw, Taylor, and Gordon, 1968), and the quality of the defence mechanisms in children with kwashiorkor against infection have been of widespread interest for a number of years. The current view is that cellmediated immunity is definitely impaired to some extent (Geefhuysen et al., 1971; Smythe et al., 1971). Serum concentrations of immunoglobulins are normal (Rosen, Geefhuysen, and Ipp, 1971), though the response to acute infection may not be optimal (Bulletin of the World Health Organization, 1972). It also appears that all nine components of serum complement are subnormal in children with severe protein energy malnutrition (Sirisinha, et al., 1973). The significance of this has not been fully elucidated.

At present, the status of neutrophil competence has not been fully determined and reports on this topic are conflicting. We therefore undertook a study of leucocyte response to infection, polymorphonuclear leucocyte (PMN) chemotaxis and bactericidal ability, and nitroblue tetrazolium (NBT) reduction in children with kwashiorkor.

\section{Patients}

The children investigated were all between 6 months and 2 years of age. They were divided into two main

Received 8 July 1974. groups. The first group consisted of 35 malnourished children, who satisfied the Wellcome criteria (Lancet, 1970) for kwashiorkor or marasmic kwashiorkor. Of these, 25 had obvious infections, 10 had pneumonia, 4 septicaemia, 3 purulent otitis media, 3 urinary tract infection, one an infected burn, and in 4 pyrexial children the infection could not be pinpointed. 7 children died. In the remaining 10 children careful clinical examination and routine investigations, including full blood count, blood culture, microscopy and culture of urine, and chest $x$-rays failed to reveal evidence of infection; one of these died.

The second group studied comprised 21 well-nourished children, all above the 10th centile for weight for age on the Harvard curves (Jelliffe, 1966). Of these, 13 had obvious infection for which they were admitted to hospital, 7 had pneumonia, 2 had pyogenic meningitis, one each had tuberculosis and gastroenteritis, and 2 children had urinary tract infections. The remaining 8 infants were uninfected and were selected from the surgical wards where they had been admitted for elective orthopaedic procedures.

For technical reasons we were unable to carry out the full battery of tests in every child. Table I shows the distr ibution of the tests done in the groups examined. Total leucocyte counts were performed on 33 of the 35 children with kwashiorkor and on 11 of 13 infected control patients. Differential white cell counts were available in 30 malnourished and 8 well-nourished infants. Full blood counts were not carried out on any of the uninfected control children. Reduction of NBT was estimated in 32 of the kwashiorkor and 20 of the control 
TABLE I

Investigations in the different groups studied

\begin{tabular}{|c|c|c|c|c|}
\hline Investigation & $\begin{array}{c}\text { Infected } \\
\text { control } \\
\text { (no. = 13) }\end{array}$ & $\begin{array}{c}\text { Uninfected } \\
\text { control } \\
(\text { no. }=8)\end{array}$ & $\begin{array}{c}\text { Uninfected } \\
\text { kwashiorkor } \\
\text { (no. = 10) }\end{array}$ & $\begin{array}{c}\text { Infected } \\
\text { kwashiorkor } \\
(\text { no. }=25)\end{array}$ \\
\hline $\begin{array}{l}\text { Total leucocyte count } \\
\text { Differential white cell count } \\
\text { NBT test } \\
\text { PMN chemotaxis } \\
\text { PMN bactericidal activity }\end{array}$ & $\begin{array}{r}11 \\
8 \\
13 \\
13 \\
9\end{array}$ & $\begin{array}{l}- \\
7 \\
8 \\
8\end{array}$ & $\begin{array}{r}9 \\
10 \\
7 \\
10 \\
10\end{array}$ & $\begin{array}{l}24 \\
20 \\
22 \\
25 \\
20\end{array}$ \\
\hline
\end{tabular}

children. PMN chemotaxis was carried out on specimens from all the children in the study and PMN bactericidal tests were performed on 28 children with malnutrition and 17 control patients. In the latter two test systems neutrophils from a normal adult were always included as a daily control.

\section{Methods}

Neutrophil chemotaxis. This was assessed using a modified Boyden chamber as described by Wilkinson (1971). Neutrophils were obtained by sedimentation from heparinized blood, and after washing in Gey's solution were then suspended in this to a concentration of $5 \times 10^{6}$ cells $/ \mathrm{ml}$. The cell suspension $(0.2 \mathrm{ml})$ was separated by a $3 \mu \mathrm{m}$ pore membrane filter (Millipore Corp.) from the chemotactic stimulus which consisted of a crude extract of casein, $5 \mathrm{mg} / \mathrm{ml}$ in Gey's solution. The same preparation was used throughout the study and consistently attracted $180-250$ cells/high power field (hpf) in normal subjects. Chambers were incubated in air for 5 hours at $37^{\circ} \mathrm{C}$ after which time filters were removed, fixed with methanol, and stained with haematoxylin. The average number of neutrophils/hpf reaching the lower surface of the filter was determined and expressed as an average per three filters.

Bactericidal ability. This was assessed using a slightly modified method of Quie et al. (1967). Neutrophils were obtained by dextran sedimentation of heparinized venous blood and after washing twice in Gey's solution were suspended to a concentration of $1 \times 10^{7}$ neutrophils/ $\mathrm{ml}$ of Gey's solution. Staphylococcus aureus were grown overnight in nutrient broth. and after washing in saline were suspended to a concentration of about $5 \times 10^{7}$ bacteria $/ \mathrm{ml}$ of Gey's solution. Each test system contained $0.1 \mathrm{ml}$ bacteria, $0.5 \mathrm{ml}$ white cell suspension (cell: bacteria ratio $1: 1$ ) and $0.4 \mathrm{ml}$ of Gey's solution containing $10 \%$ fresh normal serum. Each assay included control tubes containing the bacteria, Gey's solution with fresh serum, and $0.5 \mathrm{ml}$ Gey's solution free of leucocytes. All tubes were incubated at $37^{\circ} \mathrm{C}$ for 2 hours with end over end rotation, after which 0.1 $\mathrm{ml}$ of the mixtures were transferred into $9.9 \mathrm{ml}$ distilled water and the total number of viable bacteria determined. The difference in counts between test and control systems was assessed and expressed as the percentage of bacteria killed. Using this technique normal control subjects regularly killed 90-96\% staphylococci in 2 hours.

NBT reduction. This was assessed according to the method of Park, Fikrig, and Smithwick (1968), with modifications which have been published previously (Sher et al., 1974). These include the use of leucocyterich plasma obtained by simple sedimentation instead of whole blood, and centrifugation of the NBT reagent before use to remove insoluble debris. In our laboratory, using these procedures, we have found the mean NBT value in normal control subjects to be $2 \cdot 1 \%$ (range $0-10 \%$ ).

\section{Results}

Leucocyte counts. The results of the total leucocyte counts are given in Table II. All but one of the infected control children had a total leucocyte count of $10000 / \mathrm{mm}^{3}$ or more, whereas of the patients who had both infection and kwashiorkor, 2 had a total leucocyte count of less than 5000 and 9 a count of between 5000 and $10000 / \mathrm{mm}^{3}$.

TABLE II

Results of leucocyte counts in infected children

\begin{tabular}{|c|c|c|c|c|}
\hline \multirow{2}{*}{ No. of leucocytes $/ \mathrm{mm}^{3}$} & \multicolumn{2}{|c|}{ Infected control } & \multicolumn{2}{|c|}{ Infected kwashiorkor } \\
\hline & Alive & Dead & Alive & Dead \\
\hline $\begin{array}{l}10000 \text { or more } \\
<10000 \text { or }>5000 \\
5000 \text { or less }\end{array}$ & $\begin{array}{r}10 \\
1 \\
0\end{array}$ & $\begin{array}{l}\mathbf{0} \\
\mathbf{0} \\
\mathbf{0}\end{array}$ & $\begin{array}{r}10 \\
7 \\
0\end{array}$ & $\begin{array}{l}3 \\
2 \\
2\end{array}$ \\
\hline
\end{tabular}


4 of the 7 deaths in this group occurred in those infected patients who did not exhibit an adequate leucocyte response. The remaining death in the series occurred in a child with uncomplicated kwashiorkor.

The mean total white cell counts in infected well-nourished and malnourished patients were 18690 and $10000 / \mathrm{mm}^{3}$, respectively. This difference is significant $(P<0.0005)$. There was no statistical difference between the mean total leucocyte counts of children with kwashiorkor, who were infected as compared with those who were uninfected (10 000 and $11000 / \mathrm{mm}^{3}$, respectively).

Lymphocyte response. An absolute lymphopenia (less than $2500 / \mathrm{mm}^{3}$ ) was found in 7 out of 20 infected infants with kwashiorkor, 1 out of 9 uninfected children with kwashiorkor, and in none of the control patients. In 6 of the 8 children who died differential white cell counts were available, and 3 of them had an absolute lymphopenia.

NBT reduction. The results of the NBT reduction are shown in Fig. 1, and indicate a similar wide scatter in both malnourished and control children with infection. Among the infected patients, 2 who were well nourished, and 3 who had protein energy malnutrition, had NBT tests of less than $10 \%$, while all but 3 of the presumably uninfected children had NBT reduction of $10 \%$ or less.

PMN chemotaxis. Fig. 2 shows that in the uninfected control children the mean for PMN chemotaxis was similar to that accepted as normal for our laboratory. The infected control patients had a significantly lower mean value $(P<0.05)$. This was also found in children with infection who had kwashiorkor $(P<0 \cdot 05)$. Chemotaxis in uninfected subjects with protein energy malnutrition appeared to be unimpaired; the mean value of 244 was somewhat higher than that found among normal children, but this difference was not significant $(P>0 \cdot 1)$.

PMN bactericidal ability. Fig. 3 shows that the mean bactericidal activity in the uninfected control group was $91 \%$, normal for our laboratory. In uninfected kwashiorkor patients a similar mean was found $(88 \%)$. Infected control patients had depressed killing (mean $78 \%$ ) and infected kwashiorkor cases also had impaired killing ability (mean $82 \%$ ). The impairment of bactericidal ability in both infected groups was statistically significant $(P<0.02 ; P<0.05)$ when compared with the uninfected groups.

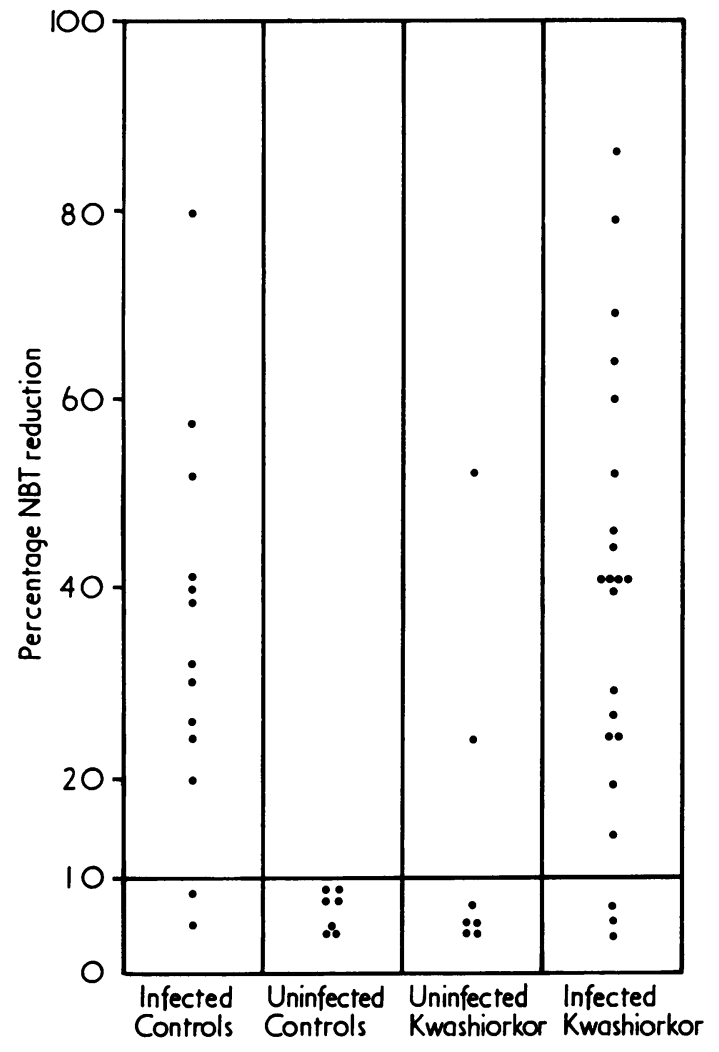

FIG. 1.-Results of NBT reduction in patient and control groups.

\section{Discussion}

There are several recent published reports on the quality of leucocyte function in children with protein energy malnutrition (PEM) (Kendall and Nolan, 1972; Freyre et al., 1973; Seth and Chandra, 1972). However, from these it is impossible to draw any definite conclusions as conflicting results have been reported.

Although failure of total leucocyte response in kwashiorkor has been documented in the past (Bulletin of the World Health Organization, 1972), there appear to be few reports on this aspect. In our study, though leucopenia was infrequent in PEM, the response to infection, as reflected by a raised total leucocyte count, was significantly depressed in the malnourished as compared with the well-nourished infected children. This is further borne out by the fact that the mean leucocyte count in infected and uninfected children with kwashiorkor was comparable.

In $33 \%$ of the infected children with malnutrition 


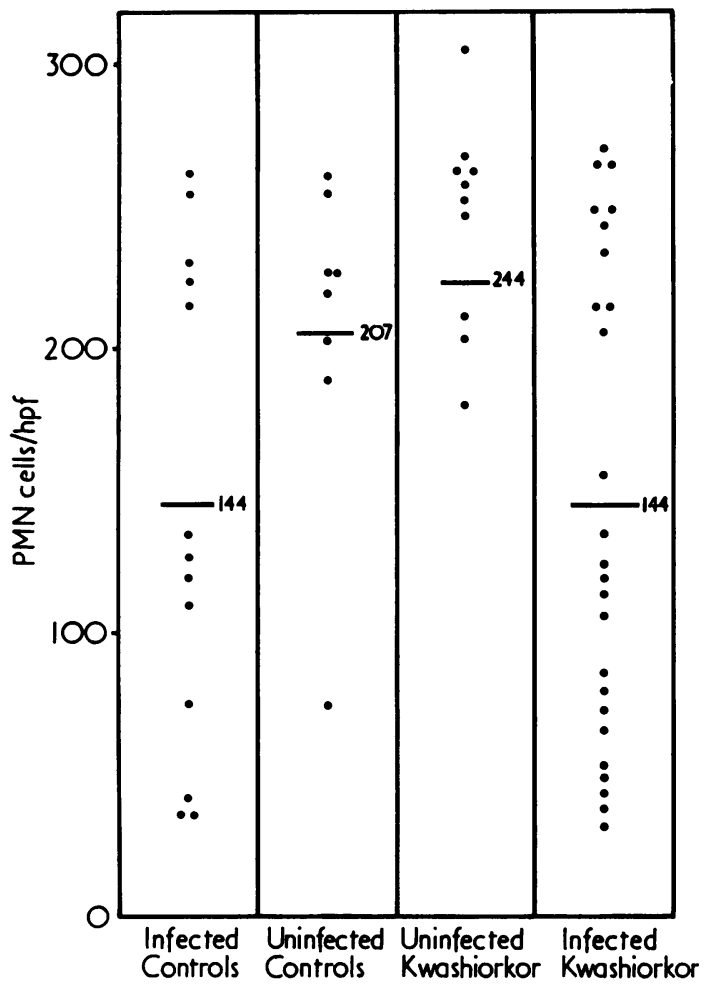

FIG. 2.-Results of PMN chemotaxis in patient and control groups.

there was a significant lymphopenia, which was not found in any of the control children. This finding may be an expression of depressed activity of the thymus-dependent lymphocyte system which has previously been documented in PEM (Smythe et al., 1971; Geefhuysen et al., 1971). The high incidence of lymphopenia has been reported previously (Chandra, 1972), but our incidence was twice that reported by Chandra, who, however, did not differentiate infected from noninfected children.

Of the three studies on the reduction of NBT in malnutrition, two concluded that reduction was impaired (Kendall and Nolan, 1972; Shousha and Kamel, 1972) and one (Altay et al., 1972) that it was normal. Our tests have shown that NBT reduction remains unimpaired in children with kwashiorkor, as in all but 3 children with infection the NBT test result was raised. The results of the present survey confirm those of Altay et al. (1972) and those more recently of Douglas and Schopfer (1974) who showed normal hexosemonophosphate shunt activity in the phagocytosing neutrophils of patients with kwashiorkor. The technique em-

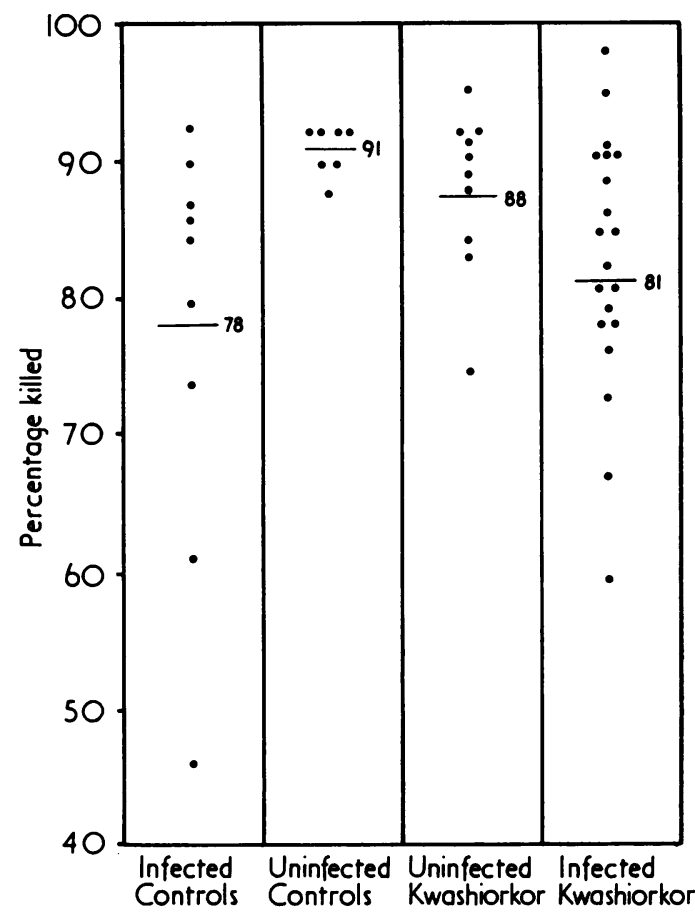

FIG. 3.-PMN bactericidal ability in patient and control groups.

ployed for the NBT test in this study has been shown to be very reliable in the diagnosis of bacterial infection (Sher et al., 1974). Thus, in the few infected children who had low NBT test results, the infection can be presumed to have been viral, both in control and malnourished patients. In the 2 children with kwashiorkor who had high NBT test results, though classified as uninfected, the possibility of a subclinical infection can also not be excluded. Variability in results between series may well be accounted for by differences in technique, as relatively small changes in procedure appear to cause considerable variation in outcome.

It has been shown previously that neutrophil chemotaxis is impaired in patients with bacterial infection (Mowat and Baum, 1971). Similarly, reduced bactericidal activity has been shown in such patients (Solberg and Hellum, 1972). McCall et al. (1971) studied the functional characteristics of toxic PMNs from patients with severe infections and showed that their response to chemotactic stimulation, as well as to phagocytic and bactericidal activity, was diminished.

It is not surprising, therefore, that in both our groups of infected patients, chemotaxis as well as 
bactericidal ability was reduced. In uninfected patients, however, chemotaxis and bactericidal capacity were normal. This indicates that depression of chemotaxis and antimicrobial ability, which was frequently found in kwashiorkor patients in this study, was primarily due to infection and not due to protein depletion. It is interesting to note that in the group of uninfected kwashiorkor patients, chemotaxis was slightly increased (though not significantly so) compared to normal children. We are as yet unable to explain this.

Seth and Chandra (1972) also studied bactericidal activity, and reported a significant decrease in killing ability of neutrophils from children with kwashiorkor. Their deductions, however, were based on the results of a group of patients in whom infection was not taken into account, as compared with normal healthy children and adults. We have shown that this is an invalid comparison and therefore cannot agree with their conclusions. Our results are comparable with those of Douglas and Schopfer (1974) whose interpretation, however, is different. Although they express their results in such a way that there appears to be a defect in the killing ability of neutrophils from kwashiorkor patients, their results indicate that PMNs from these patients do kill $90-99 \%$ of bacteria in only 60 minutes. As the details of their quantitative studies are not given, it is difficult to assess the significance of the differences which they claim exist between the bactericidal ability of 5 kwashiorkor patients and a group of control children.

Although in our study we did not assess early phagocytic events, random migration of neutrophils, or opsonic activity of serum, it appears that apart from some impairment in leucocyte mobilization the quality of PMN function is normal in kwashiorkor. We further conclude that any abnormality in PMN chemotaxis or killing ability is primarily due to infection and not to protein depletion.

We thank the Superintendent, Dr. C. Kniep, and the Head of the Department of Paediatrics at Baragwanath Hospital, Professor S. Wayburne, for permission to publish, and Professor J. D. Hansen, Head of the Department of Paediatrics of the University of the Witwatersrand, for encouragement and support. We are grateful to Dr. N. Buchanan for statistical analyses; to the Director of The South African Institute for Medical Research for facilities granted; to Professor H. J. Koornhof for criticism; and to the Department of Photography of the Witwatersrand Medical School for the illustrations.

\section{REFERENCES}

Altay, C., Say, B., Dogramaci, N., and Bingol, A. (1972). Nitroblue tetrazolium test in children with malnutrition. fournal of Pediatrics, 81, 392.

Bulletin of the World Health Organization (1972). Memorandum. A survey of nutritional immunological interactions, 46, 537.

Chandra, R. K. (1972). Immunocompetence in undernutrition. Fournal of Pediatrics, 81, 1194.

Douglas, S. D., and Schopfer, K. (1974). Phagocyte function in protein-calorie malnutrition. Clinical and Experimental Immunology, 17, 121.

Freyre, E. A., Chabes, Alvaro, Poémape, O., and Chapes Alonso (1973). Abnormal Rebuck skin window response in kwashiorkor. Fournal of Pediatrics, 82, 523.

Geefhuysen, J., Rosen, E. U., Katz, J., Ipp, T., and Metz, J. (1971). Impaired cellular immunity in kwashiorkor with improvement after therapy. British Medical fournal, 4, 527.

Jelliffe, D. B. (1966). The Assessment of the Nutritional Status of the Community. World Health Organization, Monograph Series No. 53. W.H.O., Geneva.

Kendall, A. C., and Nolan, R. (1972). Polymorphonuclear leucocyte activity in malnourished children. Central African fournal of Medicine, 18, 73.

Lancet (1970). Classification of infantile malnutrition, 2, 302.

McCall, C. E., Caves, J., Cooper, R., and DeChatelet, L. (1971). Functional characteristics of human toxic neutrophils. Fournal of Infectious Diseases ,124, 68.

Mowat, A. G., and Baum, J. (1971). Polymorphonuclear leucocyte chemotaxis in patients with bacterial infections. British Medical fournal, 3, 617.

Park, B. H., Fikrig, S. M., and Smithwick, E. M. (1968). Infection and nitroblue-tetrazolium reduction by neutrophils. Lancet, $2,532$.

Quie, P. G., White, J. G., Holmes, B., and Good, R. A. (1967). In vitro bactericidal capacity of human polymorphonuclear leukocytes: diminished activity in chronic granulomatous disease of childhood. Fournal of Clinical Investigation, 46, 668.

Rosen, E. U., Geefhuysen, J., and Ipp, T. (1971). Immunoglobulin levels in protein calorie malnutrition. South African Medical fournal, 45, 980.

Scrimshaw, N. S., Taylor, C. E., and Gordon, J. E. (1968). Interactions of Nutrition and Infection. World Health Organization, Monograph Series No. 57. W.H.O., Geneva.

Seth, V., and Chandra, R. K. (1972). Opsonic activity, phagocytosis, and bactericidal capacity of polymorphs in undernutrition. Archives of Disease in Childhood, 47, 282.

Sher, R., Anderson, R., Rabson, A. R., and Koornhof, H. J. (1974). Standardisation of the nitro-blue tetrazolium test and factors affecting its clinical application. South African Medical fournal, 48, 209.

Shousha, S., and Kamel, K. (1972). Nitro blue tetrazolium test in children with kwashiorkor with a comment on the use of latex particles in the test. Fournal of Clinical Pathology, 25, 494.

Sirisinha, S., Suskind, R., Edelman, R., Charupatana, C., and Olsen, R. E. (1973). Complement and $\mathrm{C}_{3}$-proactivator levels in children with protein-calorie malnutrition and effect of dietary treatment. Lancet, 1, 1016.

Smythe, P. M., Schonland, M., Brereton-Stiles, G. G., Coovadia, H. M., Grace, H. J., Loening, W. E. K., Mafoyane, A., Parent, M. A., and Vos, G. H. (1971). Thymolymphatic deficiency and depression of cell-mediated immunity in protein-calorie malnutrition. Lancet, 2, 939.

Solberg, C. O., and Hellum, K. B. (1972). Neutrophil granulocyte function in bacterial infections. Lancet, 2, 727.

Wilkinson, P. C. (1971). Chemotaxis of phagocytic cells towards proteins: the effect of protein denaturation. The Reticuloendothelial System and Immune Phenomena, p. 59 . Ed. by N. R. Di Luzio and K. Flemming. Plenum Press, New York.

Correspondence to Dr. A. R. Rabson, South African Institute for Medical Research, P.O. Box 1038, Johannesburg, South Africa. 